\title{
The Association between Hormonal Balance and BMI in Iraqi Women with Endometrial Cancer
}

\author{
Rana K. Jasim ${ }^{1 *}$, Salwa H. N. Al- Rubae I AndKhudhair J. S. Al-Rawaq \\ ${ }^{I}$ Psc. Student At Department Of Chemistry, College Of Science, Al-Mustansiriya University, Baghdad, Iraq. \\ ${ }^{2}$ Professor In Biochemistry, Department Of Chemistry, College Of Science, Al-Mustansiriya University, \\ Baghdad, Iraq. \\ ${ }^{3}$ Surgery Department, College Of Medicine, Baghdad University, Baghdad, Iraq.
}

\begin{abstract}
Endometrial cancer is the most common gynecologic malignancy in the United States. According to 2014 cancer statistics an estimated 52,630 cases of endometrial cancer and 8,590 of deaths cases are diagnosed in 2014.The classically diagnosis of endometrial cancer is abnormal vaginal bleeding. Most patients with this type of cancer have source of excess estrogen, high body mass index (BMI) as overweight or obese and often with other components of metabolic syndrome like hypertension.The aim of this study is investigate the role of hormonal balance and BMI in women patients with endometrial cancer. Fifty six endometrial cancer women patients mean aged (58.055 \pm 10.561 years) not submitted to therapy in this study, and $(n=30)$ healthy women volunteers mean aged $(39.731 \pm 13.504$ years) as control group. The results in this study revealed a highly significant increased $(P<0.01)$ in Estrogen $(\mathrm{pg} / \mathrm{mL})$ and Progesterone $(\mathrm{ng} / \mathrm{mL}), B M I$ $(K g / m 2), W H t R$, and WHpRin the sera levels of patients with endometrial cancer as compared to control group. The results of this study showed the risk of endometrial cancer increases linearly with increasing BMIandalso showed the association between BMI and imbalances of sex steroid when there is deficient Progesterone or excessive Estrogen with endometrial cancer women patients.
\end{abstract}

Keyword: Endometrial cancer, Estrogen (E2), Progesterone (P4) andBMI.

\section{Introduction}

Endometrial cancer is very common cancer in women and the fourth most repeatedly diagnosed cancer in the United States [1]. Irregular menstruation or postmenopausal bleeding considers symptoms to early endometrial cancer diagnosis [2]. More than $90 \%$ of women with endometrial cancer occur in women older than 50 years of age, with a median age of 63 years [3]. Hormones are substances acts as intercellular messengers that produced by the ductless glands and released into the bloodstream [4]. Chemical structures of some hormones are steroids such as female sex hormones (estrogen, progesterone) [5]. Estrogens (ES) are female sex hormones contribute in development and growth of female genital and female sex characteristics, E2are synthesized in the ovary, placenta, testes and adrenal cortex [6]. E2 functions: Sexual behavior in male and female, Secondary female sex characteristics, ovulation, support (with progesterone) uterine endometrium, Regulation of cardiovascular physiology Bone integrity and neuronal growth [7]. Progesterone (P4), also known as pregn-4-ene-3, 20-dione [8], the main source of progesterone in humans is the ovarian corpus luteum, the adrenal glands, and during pregnancy the main source of $\mathrm{P} 4$ is the placenta. $\mathrm{P} 4$ is also stored in adipose (fat) tissue [9]. Important functions of P4: regulate sexual behavior; keeping the pregnancy by inhibiting uterine contractions, promoting the development in the endometrium and the mammary gland for lactation, participate in the female menstrual/menstrual cycle and the embryogenesis of humans and other species [10]. Obesity caused endogenous overproduction of E2 mainly through changes in endogenous hormone metabolism. After menopause when ovarian stopped production of both E2 and P4, the major source of E2 become from conversion of androstenedione to estrone in adipose tissue so with obesity there is great amount of E2 in the circulation and the endometrial tissue [11]. In premenopausal women the obesity may also increase the risk endometrial cancer through hyperinsulinemia which be the mainly factor for development of ovarian hyperandrogenism, associated with anovulation and P4 deficiency [12].

\section{Materials and Methods}

Serum concentrations of hormones were measured byELISA assay, and the weight, height, waist and hip were measured.

\subsection{Subjects}

The present investigation was carried out at departments of the Medical city (Oncology teaching hospital and Baghdad hospital) in Baghdad, Iraq. The study included collection the blood samples from fifty six endometrial cancer women patients beforetherapy; age range was between 27-76 years. Thirtyhealthyfemales 
volunteers, age range was between 20-62 years served as control, also included some questionnaire regarding to age, menarche, menopause, infertility, HRT using, hypertension, personal and family history of cancer and/or diabetes mellitus, and smoking.

\subsection{Anthropometric Measurements}

Body mass index (BMI) was calculated as weight $(\mathrm{kg})$ divided by the height ${ }^{2}\left(\mathrm{~m}^{2}\right)$. Patients were taken as obese if their body mass index was 29.9 [13]. Waist: hip ratio (WHpR) was calculated by dividing waist by hip measurements [14]. Waist: height ratio (WHtR) was calculated by dividing waist by height measurements.

\subsection{Samples Analysis}

\subsubsection{Specimen collection}

Fasting blood samples $(10 \mathrm{~mL})$ were collected and placed into plane tubes. After centrifugation at $1500 \times \mathrm{g}$ for $10 \mathrm{~min}$, the sera were removed and retained for assay of the level of E2 and P4. Serum samples were stored at $-80 \mathrm{C}^{\mathrm{o}}$ until analysis.

\subsubsection{Laboratory assessmentsLaboratory assessments}

Serum concentration ofE2 and P4 were measured by ELISA test for the quantitative determination of E2 and P4 in human serum that supplied by Human Gesellschaft, Germany.

\subsection{Statistical analysis}

All data were expressed as mean \pm standard deviation (mean \pm SD). Statistical analysis was performed using LSD, considering $\mathrm{p}<0.05$ as the lowest limit of significance. Statistical analysis was performed using a software program (SPSS 13 for Windows, USA). One-way analysis of variance (ANOVA) was used to compare means with least significant difference (LSD).

\section{Results}

Table 1 displayed a highly significant increased $(\mathrm{p}<0.01)$ in ageof endometrial cancer compared to control group. There is a significant difference in systolic and diastolic blood pressure, while non-significant differences in (height and hip) between endometrial cancer patients and control groups, the majority of cancer family history and married women (presenting \%) estimated in endometrial cancer patients group, while the lowest recorded in control group. The presenting of Physical Activity and drinking coffee revealed in control group as compared to patients. Table 2 displayed a highly significant increased $(\mathrm{p}<0.01)$ in $\left(\mathrm{BMI} \mathrm{Kg} / \mathrm{m}^{2}, \mathrm{WHtR}\right.$, and WHpR), and significant increase $(\mathrm{p}<0.01)$ in $\mathrm{E} 2 \mathrm{pg} / \mathrm{mL}$ and $\mathrm{P} 4 \mathrm{ng} / \mathrm{mL}$ hormones in women patients with endometrial cancer when compared to control group. Table 3 display a highly significant increased $(\mathrm{p}<0.01)$ in P4 and non-significant differences in E2 when compared between endometrial cancer patients in different stages and control group by using ANOVA test.Table 4 showed E2 and P4 according to BMI of endometrial cancer women patients. There was significant difference $(p<0.05)$ in $\mathrm{E} 2$ between normal weight, overweight and obese of endometrial cancer patients and control group. On other hand a highly significant increased $(p<0.0001)$ was observed in $\mathrm{P} 4$ between normal weight, overweight and obese of endometrial cancer patient and control groups.

Table 1: The demographic characteristics of study women in endometrial cancer and control groups

\begin{tabular}{|c|c|c|c|}
\hline Parameters & $\begin{array}{c}\text { Controls, N=30 } \\
(\text { mean } \pm \text { SD) }\end{array}$ & $\begin{array}{c}\text { Patients, N=56 } \\
(\text { mean } \pm \text { SD) }\end{array}$ & P-value \\
\hline Age ( years) & $39.731 \pm 13.504$ & $58.055 \pm 10.561$ & $0.0001^{* *}$ \\
\hline height (m) & $1.616 \pm 0.066$ & $1.613 \pm 0.069$ & NS \\
\hline weight (Kg) & $68.153 \pm 11.202$ & $82.018 \pm 15.671$ & $0.0001^{*}$ \\
\hline waist (cm) & $85.115 \pm 16.043$ & $100.491 \pm 17.918$ & $0.0001^{* *}$ \\
\hline Hip (cm) & $109.615 \pm 16.228$ & $113.345 \pm 14.529$ & NS \\
\hline Diastolic BP (mmHg) & $7.360 \pm 1.114$ & $7.982 \pm 1.027$ & $0.02^{*}$ \\
\hline Systolic BP (mmHg) & $11.840 \pm 1.841$ & $12.927 \pm 1.259$ & $0.003^{* *}$ \\
\hline Coffee (Yes, No)\% & $(36 \%, 64 \%)$ & $(4 \%, 96 \%)$ & - \\
\hline Physical activity & $(50 \%, 50 \%)$ & $(0 \%, 100 \%)$ & - \\
\hline $\begin{array}{c}\text { Cancer family history } \\
\text { (Yes, No)\% }\end{array}$ & $(43 \%, 57 \%)$ & $(63 \%, 37 \%)$ & - \\
\hline Married (Yes, No)\% & $(60 \%, 40 \%)$ & $(82 \%, 18 \%)$ & - \\
\hline
\end{tabular}

* Significant at $\mathrm{p} \leq 0.05 * *$ Significant at $\mathrm{p} \leq 0.01$ in comparison between endometrial cancer and control group 
Table 2: Anthropometric measurement and hormonal characteristics in endometrial cancer patients and control group

\begin{tabular}{|c|c|c|c|}
\hline Parameters & $\begin{array}{c}\text { Controls, N=30 } \\
(\text { mean } \pm \text { SD) }\end{array}$ & $\begin{array}{c}\text { Patients, N=56 } \\
(\text { mean } \pm \text { SD) }\end{array}$ & P-value \\
\hline BMI $\left(\mathrm{Kg} / \mathrm{m}^{2}\right)$ & $26.138 \pm 4.405$ & $31.581 \pm 6.216$ & $0.0001^{*}$ \\
\hline WHtR & $0.780 \pm 0.114$ & $0.623 \pm 0.109$ & $0.0001^{*}$ \\
\hline WHpR & $0.528 \pm 0.104$ & $0.887 \pm 0.124$ & $0.0001^{*}$ \\
\hline $\mathrm{E} 2(\mathrm{pg} / \mathrm{mL})$ & $50.274 \pm 21.939$ & $36.539 \pm 15.540$ & $0.002^{*}$ \\
\hline $\mathrm{P} 4(\mathrm{ng} / \mathrm{mL})$ & $2.646 \pm 3.617$ & $0.367 \pm 0.509$ & $0.004^{*}$ \\
\hline
\end{tabular}

*Significant at $\mathrm{p} \leq 0.01$ in comparison between endometrial cancer and control group.

Table 3: Statistics of Hormones parameters distributed in endometrial cancer patients \& control according to stages

\begin{tabular}{|c|c|c|c|c|c|c|c|}
\hline \multirow{2}{*}{\multicolumn{2}{|c|}{ Parameters }} & \multirow{3}{*}{$\begin{array}{c}\text { Controls } \\
\text { group } \\
\mathrm{N}=30 \\
50.274\end{array}$} & \multicolumn{5}{|c|}{ Endometrial Cancer Patients } \\
\hline & & & \multirow{2}{*}{$\begin{array}{c}\begin{array}{c}\text { Stage1A } \\
\mathbf{N}=14\end{array} \\
37.883\end{array}$} & \multirow{2}{*}{$\begin{array}{c}\text { Stage1B } \\
\mathbf{N}=\mathbf{4 0}\end{array}$} & \multirow{2}{*}{$\begin{array}{c}\text { Stage II N=4 } \\
36.441\end{array}$} & \multirow{2}{*}{$\begin{array}{c}\begin{array}{c}\text { Stage III } \\
\mathbf{N}=\mathbf{1 0}\end{array} \\
36.062\end{array}$} & \multirow{2}{*}{$\begin{array}{c}\begin{array}{c}\text { Stage } \\
\text { IV } \mathbf{N}=\mathbf{8}\end{array} \\
41.799\end{array}$} \\
\hline \multirow{3}{*}{$\begin{array}{c}\mathrm{E} 2 \\
(\mathrm{pg} / \mathrm{mL})\end{array}$} & mean & & & & & & \\
\hline & SD & 21.939 & 11.689 & 15.411 & 14.383 & 20.413 & 17.802 \\
\hline & P value & \multicolumn{6}{|c|}{ NS } \\
\hline \multirow{3}{*}{$\begin{array}{c}\mathrm{P} 4 \\
(\mathrm{ng} / \mathrm{mL})\end{array}$} & mean & 2.646 & 0.298 & 0.313 & 0.347 & 0.665 & 0.244 \\
\hline & SD & 3.617 & 0.148 & 0.131 & 0.099 & 1.173 & 0.133 \\
\hline & P value & \multicolumn{6}{|c|}{$0.002 *$} \\
\hline
\end{tabular}

NS: non-significant at $p>0.05 *$ Significant at $p \leq 0.01$

Table 4: Statistics of Hormones parameters distributed in endometrial cancer \&control groups according to

\begin{tabular}{|c|c|c|c|c|c|}
\hline \multicolumn{6}{|c|}{ BMI } \\
\hline \multirow{2}{*}{\multicolumn{2}{|c|}{ Parameters }} & \multirow{2}{*}{$\begin{array}{c}\text { Control } \\
\text { group } \\
\mathrm{N}=30\end{array}$} & \multirow{2}{*}{\multicolumn{3}{|c|}{ Endometrial Cancer Patients }} \\
\hline & & & & & \\
\hline \multirow{3}{*}{$\begin{array}{c}\text { E2 } \\
(\mathrm{pg} / \mathrm{mL})\end{array}$} & mean & 50274 & 36734 & 32941 & 38050 \\
\hline & SD & 21.939 & $\frac{50.154}{13.948}$ & 13.173 & $\frac{17.104}{17.104}$ \\
\hline & P value & \multicolumn{4}{|c|}{$0.012 *$} \\
\hline \multirow{3}{*}{$\begin{array}{c}\mathrm{P} 4 \\
(\mathrm{ng} / \mathrm{mL})\end{array}$} & mean & 2.646 & 0.427 & 0.329 & 0.385 \\
\hline & SD & 3.617 & 0.189 & 0.205 & 0.666 \\
\hline & P value & \multicolumn{4}{|c|}{$0.0001 * *$} \\
\hline
\end{tabular}

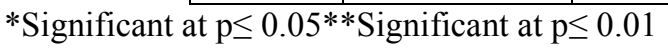

Ob: ObeseN.W: Normal weight O.W: Over weight

\section{Discussion}

Age is an important risk factor for endometrial cancer. Most women are diagnosed after menopause, The women after 40 years are the most exposure to endometrial hyperplasia it is an abnormal increase in the number of uterus cells, is not a cancer but may be develops into cancer [15]. Coffee compounds prevent the initiation phase of the carcinogenic process, decrease damage of DNA and protect cells against reactive oxygen species (ROS) [16]. The risk of endometrial cancer increased with a family history of endometrial cancer because of genetic factors [17]. Hypertension positively associated with endometrial cancer risk in models adjusted for BMI [18]. Physical activity is a modifiable risk factor related to obesity which regulates hormonal, metabolic pathways and helps control body weight, thus may protect against endometrial cancer [19].The risk of endometrial cancer increases linearly with increasing BMI, the risk is increased in women with a body mass index (BMI) greater than $30\left(\mathrm{~kg} / \mathrm{m}^{2}\right)$ [20]. Obesity causes excess of E2 because adrenal androgens are converted to E2 by adipose tissue. E2s bind directly to DNA of endometrial cell and this lead to increase transcription and interact with several growth factor signaling pathways to promote proliferation, [21, 22]. In obese premenopausal women the ovarian activity became weaker leading to markedly reduced synthesis, thus reduced $\mathrm{P} 4$ levels. The role of $\mathrm{P} 4$ in the endometrium is protective against the stimulatory effects of estrogens so decrease in normal P4 level in obese premenopausal women can increased the risk of endometrial cancer [23]. E2 act as tumor initiators, tumor promoters and increases the risk of developing endometrial cancer when exposure to E2 not opposed by P4. The mechanism is estrogen-induced stimulation of endometrial cell proliferation which promotes the probability of occurrence and accumulation of mutations [24]. P4 has the ability to resistance proliferation and promotes atrophy of the endometrium; therefor P4 and its derivatives (progestin) have been used successfully as therapeutics to treat endometrial hyperplasia and cancers [25]. Continuous exposure to imbalances of sex steroid, when there is deficient P4 or excessive E2 this can result in endometrium hyperplasia and may be then to atypical hyperplasia and endometrial cancer [26]. Obesity is one of 
the main reasons of E2/P4 hormone imbalance that may contribute to hyperplasia and carcinogenesis in the endometrium. Obesity causes an increase in endometrial cancer due to abnormal E2 levels. E2 is endometrial growth factor, after menopause the primary source of E2 is adipose tissues, adipocytes produce aromatase which converts androgens to E2 [27]. Study by McCullough et al, showed that obesity positively associated with E2 in postmenopausal breast cancer women [28]. Postmenopausal women have high E2 levels through converted aromatization of androgens in adipose tissue and increases of free E2 among overweight/obese postmenopausal women lead to promoting the development of breast cancer [29]. The unbalance between E2 and P4 lead to increases proliferation and promotion tumors growth of endometrial cells, thus increased cancer development risk to advanced stages.Also genetic mutations maybe initiated the growth of endometrial cancer, [30]. Increase E2 levels in obese individuals result from aromatized androgens and act with E2 metabolites to cause cancer, (31).Wallace et alshowed that unbalance between E2 and P4 lead to increases proliferation and promotion tumors growth of endometrial cells, thus increased cancer development risk to advanced stages[30].

\section{Conclusion}

Evidence suggests that nutrition and lifestyle factors favoring the development of obesity may increase endometrial cancer risk via effects on endogenous hormones levels. In premenopausal women may increase endometrial cancer risk by inducing chronic anovulation and P4 deficiency. In postmenopausal women may increase endometrial cancer risk by increasing bioavailable E2.

\section{Acknowledgment}

We are grateful to Dr. KhudhairJasim Al-Rawaq, associated prof. in College of Medicine/University of Baghdad, Consultant clinical oncologist at Medical city/Oncology teaching hospital, and Head of IRAQI society of clinical oncologist.

\section{References}

[1]. Siegel R., Ward E., Brawley O., and Jemal A.; Cancer statistics, 2011: the impact of eliminating socioeconomic and racial disparities on premature cancer deaths. CA Cancer J Clin 2011; 61(4):212-236.

[2]. Pfeifer S.M.; NMS obstetrics and gynecology- $7^{\text {th }}$ ed)Two Commerce Square,2001 Market Street, Philadelphia, PA 19103 , 2012 by Lippincott Williams \& Wilkins, a Wolters Kluwer business, chapter 40: Pelvic Malignancies, pp467.

[3]. European Society for Medical Oncology (2013), endometrial cancer: ESMO Clinical Practice Guidelines for diagnosis, treatment and follow-up.

[4]. Hansen B., and Jorde L. B.; KAPLAN MEDICAL, USAMLE STEP1, Lecture Notes: Biochemistry and Medical Genetics, printed in USA, Section 1: Molecular Biology and Biochemistry, Chapter9: Hormones, 2009 Kaplan, Inc. P133.

[5]. Campbell M.K., and Farrell S.O.; Biochemistry $8^{\text {th }}$ edition , 200 First Stamford Place, 4th Floor Stamford, CT 06902, USA, Chapter 24: Integration of Metabolism:Cellular Signaling, 24-3 Hormones and Second Messengers, pp 706, 707 ,2015 Cengage Learning.

[6]. Chaturvedi A.K., Engels E.A., Anderson W.F., Gillison M.L.; Incidence trends for human papillomavirus-related and -unrelated oral squamous cell carcinomas in the United States. J ClinOncol 26: 612-619 (2008).

[7]. Hu J., Zhang Z., Shen W.J., and Azhar S.; Cellular cholesterol delivery, intracellular processing and utilization for biosynthesis of steroid hormones. NutrMetab (Lond) 2010; 7: 47.

[8]. Adler N., Pfaff D., Goy R.W.; (2012). Handbook of Behavioral Neurobiology Volume 7 Reproduction (1st ed.). New York: Plenum Press. p. 189. ISBN 978-1-4684-4834-4..

[9]. Dubey R K.; SEX HORMONES, Second Edition, ISBN-10: 953-307-856-, Chapter 5; Progesterone in Human Pregnancy and Parturition, pp 100, 2015.

[10]. Senger P.L.; 2006. Pathways to pregnancy and parturition.Second revised edition ed. Current Conceptions Inc., Pullman.

[11]. Allen N.E., Key T.J., Dossus L., et al. Endogenous sex hormones and endometrial cancer risk in women in the European Prospective Investigation into Cancer and Nutrition (EPIC). EndocrRelat Cancer 2008; 15(2):485-497.

[12]. Dossus L, Allen N, Kaaks R, et al. Reproductive risk factors and endometrial cancer: the European Prospective Investigation into Cancer and Nutrition. Int J Cancer 2010; 127:442-451.

[13]. Denise R. Ferrier.BiochemistryLippincotts illustrated reviews. $6^{\text {th }}$ ed, chapter $26,2014: 349-350$.

[14]. Mohamadin AM, Habib FA, Elahi TF. Serum paraxonase 1 activity and oxidant/antioxidant status in saudi women with polycystic ovary syndrome. Pathophysiology 2010;17:189-196.

[15]. childs A.J.; Check W.E.; and Hoskins W.J.; Conservative management of endometrial hyperplasia: New strategies and experimental options, 2003.

[16]. Faustmann G., Cavin C., Nersesyan A., Knasmüller S.;Chemopreventive properties of coffee and its constituents. In Chemoprevention of Cancer and DNA Damage by Dietary Factors. Edited by Knasmüller S, DeMarini DM, Johnson I, Gerhäuser G. Weinheim, Germany: Wiley-VCH; 2009:579-594.

[17]. Bharati R., Jenkins M.A., Lindor N.M., Le Marchand L., Gallinger S., Haile R.W., et al; Does risk of endometrial cancer for women without a germline mutation in a DNA mismatch repair gene depend on family history of endometrial cancer or colorectal cancer? GynecolOncol 2014; 133:287-92.

[18]. Bjorge T., Stocks T., Lukanova A., Tretli S., Selmer R., Manjer J.; et al. Metabolic syndrome and endometrial carcinoma. Am J Epidemiol.2010; 171:892-902. [PubMed: 20219764].

[19]. Keum N., Ju W., Lee D.H., Ding E.L., Hsieh C.C., et al. (2014) Leisure-time physical activity and endometrial cancer risk: doseresponse meta-analysis of epidemiological studies. Int J Cancer 135(3): 682-694.

[20]. Royal College of Obstetricians and Gynaecologists, Endometrial Cancer in Obese Women, Scientific Impact Paper No. 32 May 2012.

[21]. MacKintosh M.L., and Crosbie E.J.; Obesity-driven endometrial cancer: is weight loss the answer?. 2013 The Authors BJOG An International Journal of Obstetrics and Gynaecology, BJOG 2013; 120:791-794. 
[22]. Khandekar M.J., Cohen P.; Spiegelman B.M., Molecular mechanisms of cancer development in obesity. Nature Rev Cancer 2011; 11:886-95.

[23]. Dowsett M., and Folkerd E.; Reduced progesterone levels explain the reduced risk of breast cancer in obese premenopausal women: a new hypothesis,Breast Cancer Res Treat, Springer Science+Business Media New York 13 November 2014.

[24]. Rižner T.L.; Review Estrogen biosynthesis, phase I and phase II metabolism, and action in endometrial cancer. Molecular and Cellular Endocrinology 381 (2013) 124-139. Elsevier Ireland Ltd.

[25]. Diep C.H., Daniel A.R., Mauro L.J., Knutson T.P., and Lange C.A.; Progesterone action in breast, uterine, and ovarian cancers, J MolEndocrinol. 2015 April; 54(2): R31-R53. Available in PMC 2015 August1.

[26]. Kim J.J., Kurita T. \&Bulun S.E.; 2013 Progesterone action in endometrial cancer, endometriosis, uterine fibroids, and breast cancer. Endocrine Reviews 34 130-162. (doi:10.1210/er.2012-1043).

[27]. Morisset A.S., Blouin K., Tchernof A.; Impact of diet and adiposity on circulating levels of sex hormonebinding globulin and androgens. Nutr Rev. 2006; 66:506-516. [PubMed: 18752474].

[28]. McCullough L.E., Miller E.E., Wang Q.,Li J., Li Liu, Li H., Zhang J., Smith J.S.; Cross-Sectional Associations between Body Size, Circulating Sex-Steroid Hormones and IGF Components among Healthy Chinese Women, PLOS ONE | DOI:10.1371/journal.pone.0137686 September 9, 2015.

[29]. Muti P.; The role of endogenous hormones in the etiology and prevention of breast cancer: the epidemiological evidence. Ann N Y Acad Sci. 2004; 1028:273-82. PMID: 15650252.

[30]. Wallace A.E., Gibson D.A., Saunders P.T.K and Jabbour H.N.; Inflammatory events in endometrial adenocarcinoma, Journal of Endocrinology (2010) 206, 141-157, Society for Endocrinology.

[31]. Gbenou G.M.C.; The influence of obesity in patients with prostate cancer - Review of the literature, Functional Foods in Health and Disease 2013; 3(4):80-93. 